\title{
The Impact of the US Military Transformation on North Korean Defence Policy
}

This article presents an interpretation of the US capacity to force North Korea to abandon the development of nuclear weapons, based on the analysis of the conventional balance between the U.S. and North Korea. It is also an attempt to evaluate the impact of the US military transformation on defence policy decisions of the potential opponents of the US. The first (theoretical) part of the article presents the assumptions of theoretical interpretation as well as the fundamentals of evaluating the conventional balance between the US and North Korea. The second part of the article highlights the key moments of the US and the international community's so far unsuccessful attempts to force North Korea to give up its nuclear weapons and explains the reasons for such unsuccessful policy. The third part of this paper analyzes the conventional balance between the US and North Korea, taking into account the conventional forces of those countries, their longrange conventional strike programmes as well as the missile defence programmes - this analysis presupposes the failure of the US to prevent North Korea from nuclear weapon development.

\section{Preface}

The US President Barack Obama in his speech in Prague in April 2009 expressed the American responsibility to strive for a world without nuclear weapons: the achievement of such goals will be possible on the condition that the states with nuclear weapons will begin the disarmament process and the states which do not possess nuclear weapons will not seek to acquire them. ${ }^{1}$ In the Nuclear Posture Review Report, published in April 2010, the US stressed its willingness to expand its negative security assurance and pledged not to use or threaten to use nuclear weapons against non-nuclear-weapon states that are in compliance with the Nuclear Nonproliferation treaty. One of the few states to pose a threat to the vision of Barack Obama is North Korea, which is developing nuclear weapon and missile technologies that would enable the

\footnotetext{
* Karolis Aleksa is a PhD candidate of the Institute of International Relations and Political Science of the University of Vilnius. Address for correspondence: Vokiečių 10, LT-01130 Vilnius, Lithuania, tel.: + 3705 2514130, e-mail - karolisaleksa@hotmail.com

${ }^{1}$ Remarks by President Barack Obama, Hradcany Square, Prague, Czech Republic, April 5, 2009, http://www.whitehouse.gov/the_press_office/Remarks-By-President-Barack-Obama-In-Prague-AsDelivered/, 1008 2010 .
} 
use of nuclear weapon against the US. On April 5, 2009, the day of Obama's speech in Prague, North Korea launched a rocket that could be used to produce an intercontinental ballistic missile, and on May 25 this country made a second test of the nuclear weapon. It seemed that Barack Obama's speeches (before he was elected the President of the US²) regarding North Korea, in which he urged the administration of the former US President, George W. Bush, to engage more actively in direct discussions with North Korea, could deter North Korea from such actions. Analysts express different views on North Korea's actions as well as on the entire foreign policy of North Korea after the cold war. Recently there appeared more analytical studies, which aim to dissipate the image of North Korea as an irrational and unpredictable actor of international relations that was largely shaped by global media and was mainly escalated through the policy and rhetoric of George W. Bush, the former President of the US ${ }^{3}$. Some analysts claim that the foreign policy of North Korea is determined by its strategic culture developed by Kim IlSung, the founder of North Korea, and that it is not itself irrational'; whereas others maintain that North Korea's policy is conditioned by its vital defence interests that can be explained rationally ${ }^{5}$. Other researchers who have tried to assess North Korean negotiating behaviour also claim that North Korea is not an irrational state which could not be deterred (in fact the strategy of North Korean deterrence has already been successfully effective for more than fifty years) ${ }^{6}$ and that this country implements a calculated aggressive diplomatic strategy, which pursues benefits by provoking crises. ${ }^{7}$ Furthermore, the researchers claim that North Korea deliberately tries to build an image of an unpredictable state that is prepared to take a huge risk in case the US or South Korea would start to implement sanctions or refuse to make concessions. ${ }^{8}$

The majority of analysts, while assessing the possibilities and means of the US and international community to force North Korea to give up its nuclear

\footnotetext{
${ }^{2}$ See for example: The Candidates on North Korea Policy, October 23, 2008, http://www.cfr.org/publication/14757/candidates_on_north_korea_policy.html, 11082010.

${ }^{3} \mathrm{See}$ an interesting and informative analysis by Hugh Gusterson, which reveals distorted and incorrect assessments of North Korean leaders and policy in the US print media. Gusterson H., "Paranoid, Potbellied Stalinist Gets Nuclear Weapons: How the U.S. Print Media Cover North Korea", Nonproliferation Review, Vol. 15, No. 1, March 2008, p. 30-35.

${ }^{4}$ Bermudez J. S. Jr., "North Korea and the Political Uses of Strategic Culture" in Johnson J.L, Kartchner K.M., Larsen J.A., ed., Strategic Culture and Weapons of Mass Destruction: Culturally Based Insights With Comparative National Security Policymaking. New York: Palgrave Macmillan, 2009, p. 189-200. ${ }^{5} \mathrm{O}$ 'Neil A., Nuclear Proliferation in Northeast Asia: The Quest for Security. New York: Palgrave Macmillan, 2007, p.57-58, 74.

${ }^{6}$ Cha V. D., Kang D. C., Nuclear North Korea: A Debate on Engagement Strategies, New York, West Sussex: Columbia University Press, 2003; O'Neil A., Nuclear Proliferation in Northeast Asia: The Quest for Security. New York: Palgrave Macmillan, 2007, p. 75.

${ }^{7}$ Huntley Wade L., "Bucks for the Bang: North Korea's Nuclear Program and Northeast Asian Military Spending", Asian Perspective, Vol. 33, No. 4, 2009, p. 147-182.

${ }^{8}$ Kim Yongho, Yi Yurim, "Security Dilemmas and Signaling during the North Korean Nuclear Standoff", Asian Perspective, Vol. 29, No.3, 2005, p. 73-97.
} 
weapon programme, believe that this is possible and that the negotiations still remain the best instrument to achieve this goal. M. O'Hanlon and M. Mochizuki claim that the requirements for North Korea must be raised along with certain incentives to make reforms ${ }^{9}$. Such a position is supported by other analysts who pay much attention to the consensus building within international community (especially among the states which participate in the six-party talks on North Korea's issue). For example, Chung-in Moon and Jong Yun Bae believe that the six-party talks should be continued and that the U.S. should hold a slightly more flexible position ${ }^{10}$. Wade L. Huntley also claims that it is not sufficient to deal only with North Korea, it is also very important to build a consensus among the U.S., Japan, Russia, China and South Korea ${ }^{11}$; G. Chang emphasizes the key role of South Korea in building a common consensus: South Korea pursues North Korea's engagement policy, which actually facilitates North Korean attempts to further develop nuclear weapons programme, and gives a chance for China to exploit this policy for its own benefit. ${ }^{12}$

It is possible to recognize the value of such argumentation because pressure from the international community on Libya eventually forced this state to abandon its nuclear weapons development programme ${ }^{13}$; and Saddam Hussein's regime, which resisted international pressure, was overthrown. The cases of Libya and Iraq should provide North Korean leaders good reasons to abandon the nuclear weapons development programme. However, North Korea has not abandoned it yet.

With this in mind, this article aims to present another interpretation of the US capacity to force North Korea to abandon its nuclear weapons development programme. This interpretation is rather pessimistic as it explains that the increasing US conventional military superiority against conventional forces of other states is one of the main factors which determines today and will determine in the future the North Korean policy to develop a nuclear weapons arsenal.

The idea that the growing conventional superiority of the US after the cold war stimulates the proliferation of the weapons of mass destruction is

\footnotetext{
${ }_{9}^{9}$ O’Hanlon M., Mochizuki, M. M., Crisis on the Korean Peninsula: How to Deal with a Nuclear North Korea. Blacklick, OH, USA: McGraw-Hill Professional Publishing, 2003, p. 4-6.

${ }^{10}$ Despite the fact that these ideas were expressed seven years ago, they have not become outdated, having in mind the contemporary situation in the six-party talks with North Korea. See Moon Chung-in, Bae Jong-Yun, „The Bush Doctrine and the North Korean Nuclear Crisis“, Asian Perspective, Vol. 27, No.4, 2003, p.9-45.

${ }^{11}$ The consensus building between the US and China is considered to be a key element of the process. See Huntley Wade L., "Bucks for the Bang: North Korea's Nuclear Program and Northeast Asian Military Spending", Asian Perspective, Vol. 33, No. 4, 2009, p.147-182.

${ }^{12}$ However in 2008, when Lee Myung bak, who is more sceptical regarding North Korea's intentions than his predecessors Kim Dae-Jung and Roh Moo-Hyun, was elected the President of South Korea, conditions for the consensus building became more favourable. See. Chang G., Nuclear Showdown: North Korea Takes on the World. Westminster, MD, USA: Random House, Incorporated, 2006, p. 200-220.

${ }^{13}$ See e.g., Squassoni S., Disarming Libya: Weapons of Mass Detruction. CRS Report for Congress, September 22, 2006, http://fpc.state.gov/documents/organization/78338.pdf, 20112010.
} 
not original ${ }^{14}$. However, this article argues that this development is one of the most important factors determining North Korea's decisions regarding further development of nuclear weapons today and in the future. The effect of this factor cannot even be neutralized by the possible US security guarantees for North Korea.

The first part of the article presents the assumptions of theoretical interpretation and the foundation of analysis that grounds the interpretation itself. The second part overviews the history of the US and international community's attempts to force North Korea to give up its nuclear weapon development, highlighting the essential problems which deprived the US and international community of attaining North Korea's nuclear disarmament. The third part of this paper, following the analysis of conventional balance between the US and North Korea, provides conclusions regarding the US capacity to force North Korea to abandon its nuclear weapons.

Finally, the North Korea "problem" deserves attention from Lithuania's foreign and defence policy decision makers. Possible armed conflict between the US and North Korea is the main reason why they should care about this issue. In the worst case scenario, if armed conflict between US/South Korea and North Korea broke out, NATO would have to consider the question of support for the US and South Korea, a close ally of the US and a partner of NATO, during and after the conflict. Even if this worst-case scenario does not materialize, one should not reject the possibility of the collapse of the North Korean regime - if this were to happen, the North Korean people would require urgent humanitarian aid. In both cases Lithuania would need to react to the situation in North Korea.

\section{Theoretical Assumptions and Explanatory Criteria}

In the 1990s a great number of studies by US analysts and military officers were published, which suggested that the US was on its way towards revolution in military affairs and that this revolution would provide the US with an unlimited military superiority against any potential enemy. In the first decade of this century, taking into account the progress in the US military, there was an increasing number of those who claimed that the revolution in military affairs did not happen, although some elements may be recognised it. A growing wariness to openly declaring the beginning of the era of revolution in military affairs is revealed by a change of concepts in the speeches and writings of the state officials, military officers and academic researchers of the US: in the first decade of this century the concept of 'revolution in military affairs' was substituted with such concepts as 'military transformation' and 'modernization

\footnotetext{
${ }^{14}$ See Gerson M.S, „Conventional Deterrence in the Second Nuclear Age“, Parameters, Autumn 2009, http://www.carlisle.army.mil/USAWC/parameters/Articles/09autumn/gerson.pdf, 2011 2010; Morgan P.M., Deterrence Now. Cambridge: Cambridge University Press, 2003, 203-237.
} 
plus' ${ }^{15}$ However, despite a decreasing belief in the revolution in military affairs after the cold war $^{16}$, the elements of such revolution are still visible in the US military progress. Such elements are reflected in various analytical studies that examine different ways and means by which certain states respond to the military progress of the US; the analysis based on the reaction of the US allies (the United Kingdom, Australia, France, Germany, and Israel $)^{17}$ has received the greatest attention so far. These studies aim to reveal the view of the allies towards the phenomenon of the revolution in military affairs itself as well as to specifically identify the modernization programmes of ally military forces which reflect a response to the revolution in military affairs. In the research on the reaction of the potential US opponents, greater attention was paid to

\footnotetext{
${ }^{15}$ Raska M., The RMA Theory, Process, and Debate: "Five Waves", Lee Kuan Yew School of Public Policy: Working Paper Series (SPP10-06), September 2010, http://www.spp.nus.edu.sg/docs/wp/2010/ wp1006.pdf, 1509 2010. See also Sloan E., Military Transformation and Modern Warfare: A Reference Handbook. Westport, Connecticut, London: Praeger Security International, 2008; Gates, R.M., "A Balanced Strategy: Reprogramming the Pentagon for a New Age". Foreign Affairs, January/February 2009, Vol.88, No.1, p. 28-40.

${ }^{16}$ Aleksa K., "Karinio pokyčio poveikio tarptautinei sistemai interpretacijos", Lietuvos Metinė Strateginė Apžvalga 2009-2010, Vilnius: Generolo Jono Žemaičio Lietuvos karo akademija, 2010, p. 28.

${ }^{17}$ Sloan E., Military Transformation and Modern Warfare: A Reference Handbook. Westport, Connecticut, London: Praeger Security International, 2008; Sloan E., Canada and the Revolution in Military Affairs: Current Response and Future Opportunities, http://www.journal.forces.gc.ca/vo1/no3/doc/7-14-eng. pdf, 0508 2010; Raska M., The Revolution in Military Affairs and Security of Small States: Israel's RMA Trajectory and Force Modernization Programs (1995-2008), Lee Kuan Yew School of Public Policy, Working Paper Series,

http://www.spp.nus.edu.sg/wp/2009/wp0904.pdf, 0508 2010; see Laird R.F., Mey H.H., The Revolution in Military

Affairs: Allied Perspectives, Institute for National Strategic Studies, National Defence University, Washington, 1999,

http://www.isn.ethz.ch/isn/Digital-Library/Publications/Detail/?ots591=0c54e3b3-1e9c-be1e-2c24a6a8c7060233\&lng=en\&id=23633, 0509 2010; Collmer S., Information as a Key Resource: The Influence of RMA and Network-Centric Operations on the Transformation of the German Armed Forces, George C.Marshall European Center for Security Studies, Occasional Paper Series, No. 8, February 2007, http://www.marshallcenter.org/mcpublicweb/MCDocs/files/College/F_Publications/occPapers/occpaper_8-en.pdf, 05
}

09 2010; Donnelly C., How do Allies Deal With U.S. Military Transformation,

http://www.nids.go.jp/english/event/symposium/pdf/2005/e2005_06.pdf, 0509 2010; Bernard S., The

Revolution in

Military Affairs: Approach with Caution. The Army Doctrine and Training Bulletin, Vol 3, No.4/Vol. 4, No. 1, Winter

2000/Spring 2001, http://www.army.forces.gc.ca/caj/documents/vol_03/iss_4/CAJ_vol3.4_13_e.pdf, 05 092010 ;

Richter A., The Revolution in Military Affairs and its Impact on Canada: The Challenge and the Consequences. Institute of International Relations, The University of British Columbia. Working paper No. 28, March 1999, http://www.isn.ethz.ch/isn/Digital-Library/Publications/Detail/?ord655=grp1\&ots591=0c54e 3b3-1e9c-be1e-2c24-a6a8c7060233\&lng=en\&id=46514, 05092010. 
the response of China to the US military progress ${ }^{18}$; however, there is little research on the reaction of other potential opponents (such as Russia, Iraq, North Korea and etc.). ${ }^{19}$

Reviewed literature suggests no model of how to analyse the impact of the US military transformation on the potential US opponents (Iran, North Korea) which, unlike Russia and China, are not able to equally compete with the US in the field of military progress. In this article a theoretical analysis of the conventional balance between the US and North Korea is undertaken to show the impact of the US military transformation on the defence policy of North Korea. In order to reveal the shift in this balance, the following explanatory criteria will be analysed: the level of modernization of conventional forces of the US and North Korea ${ }^{20}$, the tendencies of the development of the US missile defence and North Korean ballistic missile programmes, the US long-range conventional strike programme and North Korea's capabilities to defend against this programme. The criteria of the US conventional force modernization programme as well as the US missile defence and long-range conventional strike programmes are chosen because they represent distinctive elements of the US military transformation after the cold war. The US missile defence programs are important because they enhance US conventional defence capabilities against nuclear attacks; the long-range conventional strike programs are special because they can neutralise nuclear weapons with minimal destructive power. The analysis of these criteria has the potential to reveal the characteristics of the development of the conventional balance between the US and North Korea and to highlight North Korea's dilemmas of defence. The selected criteria make the analysis of the conventional balance shift between the US and North Korea different from a standard (classical) conventional analysis, the aim of which would be to compare the overall size of the US and North Korean conventional forces, the number of different conventional weapons or at least to compare the size of the US conventional forces and US conventional weaponry in South Korea with North Korea's conventional forces. However, in this case the standard analysis of the conventional balance is unable to reveal the qualitative aspects of the balance shift which influences North Korea's

\footnotetext{
${ }^{18}$ Gill B., Henley L., China and the Revolution in Military Affairs. Strategic Studies Institute, 1996, www.strategicstudiesinstitute.army.mil, 0909 2008; Yoshihara T., Chinese Information Warfare - A Phantom Menace or Emerging Threat. Strategic Studies Institute, 2001, http://www.au.af.mil/au/awc/awcgate/ ssi/chininfo.pdf, 05092010 ; Mulvenon J.C., Tanner M.S., Chase M.S., Frelinger D., Gompert D.C., Libicki M.C., Pollpeter K.L., Chinese Responses to U.S. Military Transformation and Implications for the Department of Defence. RAND, 2006, http://www.rand.org/pubs/monographs/2006/RAND_MG340.pdf, 2009-07-20; Jun W., Xiangli S., Side H., The Impact of Revolution in Military Affairs on China's Defence Policy, http://www.lincei.it/rapporti/amaldi/papers/XVWuRMAImpact.pdf, 25082008.

${ }^{19}$ Boot, M., War Made New: Weapons, Warriors, and the Making of the Modern World. New York: Gotham Books, 2006; Hoyt T.D., "Revolution and Counter-Revolution: The Role of the Periphery in Technological and Conceptual Innovation", 179-201 in Ed. By Goldman E.O., Eliason L.C., The Diffusion of Military Technology and Ideas, California: Stanford University Press, 2003.

${ }^{20}$ In this article the modernization level criterion measures the capability of conventional forces to fight modern wars (e.g., US and international coalition's military operation against Iraq in 2003).
} 
policy to further seek nuclear weapon programme. The standard comparative analysis of all US and North Korean conventional forces during the period of 1990-2010 shows that the US has greater active conventional forces, more tanks, infantry fighting vehicles, submarines and battleships, the number of which had decreased after the cold war, yet in 2010 it still remains larger than in North Korea. ${ }^{21}$ The comparative analysis of the US conventional forces in South Korea versus North Korea's conventional forces and weapons shows the quantitative superiority of North Korea (however, North Korean quantitative superiority becomes a marginal one if compared against both US conventional forces in South Korea and South Korean conventional forces ${ }^{22}$. It is possible to recognize the value of the standard conventional balance in case when the conventional forces of North Korea and South Korea are compared: such an analysis shows increasing South Korean qualitative superiority in the field of conventional weaponry, which reflects the impact of US military support.

However, this article focuses on the direct impact of the US military transformation on North Korea's defence policy. After all, the examples of the Korean War (1950-1953) and military operations in Iraq show that the quantitative superiority of the enemy forces had not prevented the US forces from achieving military victories. Furthermore, in its operational plans the US is planning to deploy from 480000 to 690000 soldiers for the military conflict with North Korea, ${ }^{23}$ which together with South Korean forces would be equal to North Korean forces in quantity (excluding the reserve forces of both North Korea and South Korea) and would undoubtedly be qualitatively superior to North Korean forces. ${ }^{24}$ The limitation of the standard conventional analysis in North Korea's case therefore leads to the choice of the analysis of the conventional balance between the US and North Korea, which reveals qualitative changes according to the chosen criteria; such analysis explains the defence policy of North Korea in seeking further nuclear weapons development.

\footnotetext{
${ }^{21}$ E.g., in 2009 US had: 1153587 active forces troops, 7620 tanks, 28574 armoured vehicles, 1200 active fighter aircrafts; North Korea in 2009 had: 1106000 active forces troops, 4010 tanks, approximately 2500 armoured vehicles and about 620 active fighter aircrafts. In 1990 this balance was even more favourable to the US. See The Military Balance 2009. The International Institute for Strategic Studies. London: Routledge, Taylor\&Francis Group, 2009, 31-44, 394-396.

${ }^{22}$ In 2009 US has maintained about 25000 troops in South Korea and South Korean active forces consisted of 687000 troops - some 300000 less than North Korea; besides, South Korea had about 2330 tanks, 491 active fighter aircrafts and approximately 2330 armoured vehicles, i.e., less than North Korea. See The Military Balance 2009. The International Institute for Strategic Studies. London: Routledge, Taylor\&Francis Group, 2009, 396-398.

${ }^{23}$ OPLAN 5027 Major Theater - West, http://www.globalsecurity.org/military/ops/oplan-5027.htm, 20112010.

${ }^{24}$ However, North Korea may not approve of such estimation.
} 


\section{The History of Failure: the US Attempts to Force North Korea to Abandon its Nuclear Weapons Development Programme}

After North Korea had declared its withdrawal from the Nuclear NonProliferation Treaty in March 1993, the US took leadership in managing the crisis, which could have had a negative influence not only on the effectiveness of the nuclear non-proliferation regime, but also on the entire stability of the East Asian region. On October 21, 1994 the US and North Korea agreed in Geneva that North Korea would freeze its nuclear reactors within the course of one month after signing the agreement in exchange for the US obligation to supply North Korea with 500,000 metric tons of heavy oil annually and to construct light-water nuclear power reactors that would be able to generate 2000-megawatt energy annually. The US also agreed to provide formal assurances to North Korea that it would not threaten to use or use nuclear weapons against North Korea (if the 1994 Agreement will be implemented); in addition, North Korea committed to remain a party to the Nuclear Non-Proliferation Treaty. ${ }^{25}$ North Korea shut down the Yongbyon nuclear plant and the plutonium production reactors; however the spent nuclear fuel was not shipped from North Korea.

The Agreed Framework of 1994 between the US and North Korea officially collapsed in October 2002, when the US announced that during bilateral talks North Korea admitted to the US that it had been running a uranium-enrichment programme for nuclear weapons production. Although North Korea publicly denied these accusations, in November 2002 the US suspended the heavy oil shipments in accordance with the Agreed Framework of 1994. In response to these actions, North Korea resumed the operation of Yongbyon nuclear plant, expelled the International Atomic Energy Agency's inspectors from the country and withdrew from the Nuclear Non-Proliferation Treaty. However, the implementation of the Agreed Framework of 1994 had not been transparent even before its formal collapse: the US intelligence had information that North Korea was secretly running a uranium-enrichment programme; besides, these suspicions kept the US from well-timed supply of heavy oil and allocation of necessary funds for the construction of light-water nuclear reactors. ${ }^{26}$ Therefore, in 1998 the US initiated a review of North Korea's policy, which was essentially justified by continuous North Korea's activities

\footnotetext{
${ }^{25}$ However, visits of the International Atomic Energy Agency's inspectors to North Korea were postponed until progress in construction of light-water power reactors is achieved. See Agreed Framework Between the United States of America and the Democratic People's Republic of Korea, October 21, 1994, http:// www.armscontrol.org/documents/af,05 08 2010. Also see Hassig R.C., Oh K., North Korea: A Rogue State Outside the NPT Fold, http://www.america.gov/st/peacesec-english/2005/March/20080815121936X JyrreP9.679812e-02.html, 01082010.

${ }^{26}$ Drifte R., The Perry Report and US-North Korea Relations, ASIEN 79 (April 2001), http://www.asienkunde.de/content/zeitschrift_asien/archiv/pdf/Drifte79.pdf, 07082010.
} 
in developing nuclear weapons and long-range missiles ${ }^{27}$. The review of the US policy towards North Korea expressed a direct concern about North Korea's possible nuclear weapon development activities; however, due to the lack of direct evidence it was recommended that North Korea make ultimate and verifiable assurances that it will not engage in the development of the nuclear weapon programme and also it compelled North Korea to abide by the Missile Technology Control Regime. ${ }^{28}$ In case such strategy failed to be realized, it was recommended that threat management measures be taken; however, according to the report, a military operation against North Korea was dismissed at that time.

The crisis which began at the end of 2002 was temporarily solved by the agreement of September 19, 2005 among North Korea, the US, China, Russia, South Korea and Japan. Under this agreement, North Korea was required to give up its nuclear weapons, to freeze the nuclear development programmes, to rejoin the Nuclear Non-Proliferation Treaty and to re-admit the International Atomic Energy Agency's inspectors. The US affirmed that it had not deployed any nuclear weapons in the Korean peninsula and that it had no intention of attacking North Korea with any conventional or nuclear weapons. ${ }^{29}$ However, shortly afterwards this agreement collapsed; in July 2006, North Korea test-fired its missiles and conducted a detonation of a nuclear device in October of the same year. This crisis was temporarily solved by the agreement of February 2007 among the six states that were mentioned above; under this agreement North Korea was obliged to shut down the Yongbyon nuclear reactors, to destroy its nuclear weapons and to present a list of the nuclear materials and facilities that it possesses. Although in the summer of 2008 the US official representatives recorded obvious progress in the implementation of the agreement of 2007 (in July 2007 the Yongbyon nuclear reactors were shut down; later in October North Korea agreed to shut down other facilities at Yongbyon) ${ }^{30}$, however, at

\footnotetext{
${ }^{27}$ Review of United States Policy Toward North Korea: Findings and Recommendations, Unclassified Report by Dr. William J. Perry, U.S. North Korea Policy Coordinator and Special Advisor to the President and the Secretary of State, Washington, DC, October 12, 1999, http://www.state.gov/www/regions/ eap/991012_northkorea_rpt.html, 05082010.

${ }^{28}$ Back in October 1998, the member states of the Missile Technology Control Regime urged North Korea to constrain its actions related to the development and proliferation of long-range missile technologies and agreed to deny support for North Korean missile technology programmes. See Chairman's Statement on North Korean Missile Proliferation Activities, 1998, Missile Technology Control Regime, http://www. mtcr.info/english/public/1998.html, 05082010.

${ }^{29}$ Katzman K., U.S.-North Korean Relations: An Analytical Compendium of U.S. Policies,

Laws\&Regulations, the Atlantic Council of the United States, Occasional Paper, March 2007, http://www. acus.org/docs/070413_USNorth_Korean_Relations_Analytic_Compendium.pdf, 05082010.

${ }^{30}$ Deputy Administrator William Tobey, Testimony on "The North Korean Six-Party Talks and Implementation Activities" before the Senate Armed Services Committee, http://nnsa.energy.gov/mediaroom/congressionaltestimony/07.31.08, 0508 2010. In his speech Tobey mentioned that North Korea would need a year or more in order to re-establish plutonium production capacities in the Yongbyon complex.
} 
the end of 2008 a lack of progress in the six-party talks was sensed. ${ }^{31}$ In spring 2009, after launching a long-range missile and after facing condemnation by the international community, North Korea withdrew from the six-party talks; then on May 25 North Korea tested its second nuclear device and said that this action was conducted in order to bolster its nuclear deterrence and self-defence. ${ }^{32}$ The US - North Korean relations became strained after March 26, 2010 when the South Korean corvette Cheonan was sunk; this had allegedly been caused by a North Korean submarine. The war-games of the US and South Korea, which took place in August 2010, were assessed by North Korea as a demonstration of an unchanging wild desire on the part of the US to dominate the world and in the Korean peninsula. ${ }^{33}$

Thus, despite the efforts of the US and the international community to force North Korea to give up its nuclear weapon development programme, North Korea managed to conduct two nuclear device tests: during the first test around 0.5-0.8 kilotons of plutonium were detonated, and during the second test 2-4 kilotons were exploded (these were not large-scale tests, considering that the US and the USSR during their first nuclear tests exploded more than 20 kilotons of plutonium). ${ }^{34}$ According to Wade L. Huntley, during the period of 1989 - 2009 North Korea produced approximately 41-67 kilograms of plutonium; such amount could be used to produce around 2 to 16 ballistic missile warheads. However, due to disagreement whether the second nuclear test of North Korea reveals any technological progress of nuclear device production, it is also difficult to estimate the North Korean progress in manufacturing nuclear warheads which could be mounted on ballistic missiles. Although back in 1994 certain US intelligence agencies warned the US Government about North Korean capacities to mount the nuclear warhead Nodong on medium-range ballistic missiles by 2000 (or even by 1995), this was not confirmed in later official or academic sources. Nevertheless, there are claims being made that North Korea is undoubtedly making progress in producing nuclear warheads for ballistic missiles.

Analysis of the US-North Korean relations after the cold war, the dynamics of which was determined by the problem of the nuclear weapon development programme, implies some preliminary conclusions: firstly, any progress in curbing North Korea's ambitions of nuclear weapon development is blocked by differing objectives of the US and North Korea. The US maintains

\footnotetext{
${ }^{31}$ See Kim I., The Six-Party Talks and President Obama's North Korea Policy, Monterey Institute for International Studies, James Martin Center for Nonproliferation Studies, February 2009, http://www.nti. org/e_research/e3_six_party_obama_north_korea.html, 05082010.

${ }^{32} \mathrm{KCN}$ A Report on One More Successful Underground Nuclear Test, May 25, 2009, http://www.kcna. co.jp/indexe.htm, 05082010.

${ }^{33}$ U.S. Warmongers Accused of Stepping up Military Moves against the DPRK, May 26, 2010, http://www.kcna.co.jp/index-e.htm, 09082010.

${ }^{34}$ Huntley Wade L., "Bucks for the Bang: North Korea's Nuclear Program and Northeast Asian Military Spending", Asian Perspective, Vol. 33, No. 4, 2009, p. 155.
} 
that North Korea, first of all, has to give up its nuclear weapon development programmes, and only then it will be possible to start negotiations regarding a peace treaty (which had not been signed after the Korean war of 1950-1953) as well as security guarantees and economic aid from the US. However North Korea declares that, first of all, it demands a peace treaty and security guarantees which will only then be followed by North Korean nuclear disarmament. Secondly, it seems that in principle North Korea is not prepared to give up its nuclear weapon development programme: the evidence possessed by the international community suggests that North Korea is engaged (or is trying to engage) in several parallel programmes for producing nuclear warheads for short-range, medium-range and long-range ballistic missiles. North Korea's obligations in agreements demonstrate the state's capability to use diplomatic means to gain its own ends, i.e. in order to develop a nuclear shield.

\section{The Growing Military Superiority of the US: the Interpretation of the Impact on North Korean Defence Policy}

\subsection{Elements of US Military Superiority}

\subsubsection{Strategic Attitudes}

The US strategic attitudes which define threats and modes of response to them not only retained many significant formulations of the past, but were also complemented by important new aspects after the defence policy review of 2009-2010, which was delivered by the administration of President Barack Obama. The review of strategic attitudes sent a few important messages to the US opponents. Firstly, the US will try to preserve its military superiority against any potential opponent ${ }^{35}$ and to consolidate and reform international order together with its allies and partners. Secondly, the US hopes to preserve its military superiority against its opponents by diminishing the role of nuclear weapons in national defence policy: the US declared that it would not threaten to use or use nuclear weapons against non-nuclear-weapon states which are the parties to the Nuclear Non-Proliferation Treaty and act in accordance with their obligations under this Treaty. ${ }^{36}$ In the report of the defence policy review the US also noted that although the nuclear weapon can be used in response to non-nuclear attacks (conventional, chemical or biological), the probability of such use is heavily diminished. Such confidence of the US in its military

\footnotetext{
${ }^{35}$ See Quadrennial Defence Review Report, February 2010, p.iv., http://www.defense.gov/qdr/images/ QDR_as_of_12Feb10_1000.pdf, 07082010.

${ }^{36}$ Nuclear Posture Review Report, April 2010, p.viii,

http://www.defense.gov/npr/docs/2010\%20Nuclear\%20Posture\%20Review\%20Report.pdf, 07082010.
} 
superiority is related to the significantly increased conventional power - it is openly declared in the Quadrennial defence and Nuclear Posture reports. Although the US recognizes an increased threat of nuclear and ballistic missile attacks, it maintains that the elements of its conventional power, such as modern and rapidly deployable forces, strikes with precision-guided weapons and global missile defence, will help to deter such threats or to respond to them efficiently.

In the US defence policy review reports, ${ }^{37}$ North Korea is described as a state which violated the Nuclear Weapon Non-Proliferation Treaty, failed to comply with the United Nations Security Council's decisions, developed long-range missiles and resisted the efforts of the international community to solve these problems. The US declares that in concert with the international community it will use diplomatic measures to solve the North Korean nuclear issue; however it does not reject the possibility of taking other measures.

US defence policy formulations should lead North Korean leaders to draw several fundamental conclusions: firstly, the US military superiority against any potential opponent and the US aim to preserve this superiority continues to remain one of the main security dilemmas for the US opponents (including North Korea); secondly, in case North Korea refuses to comply with the demands of the US and international community to abandon its nuclear weapon and long-range missile development programmes, it may face US military force; thirdly, even after abandoning these programmes North Korea will still remain a potential target of the US nuclear strike, because it will retain the chemical and biological weapons in its arsenal.

\subsubsection{Increase of US Military Superiority against North Korea}

It is a very challenging task to accurately assess the US military superiority against North Korea without secret intelligence data. However, the available information about the transformation pace of the US conventional forces and status of North Korean military forces provides a pretty clear picture of the growing US military superiority over North Korea. This article argues that the increased US military superiority against North Korea is determined by the following factors: the transformation of the US conventional forces, a rapid development of the global missile defence system and theatre missile defence systems, as well as the development of Conventional Prompt Global Strike Programme.

The transformation of conventional forces, which is enabled by the development of modern information and communication and precision-guided weapons technologies, provided the US conventional forces with immeasurable

\footnotetext{
${ }_{37}$ Quadrennial Defence Review Report 2010, Nuclear Posture Review Report 2010, Ballistic Missile Defence Review Report 2010.
} 
superiority over other countries. Modern technologies made it possible for the US conventional forces to collect and process information at great speed, then make decisions and take actions in battlefield quickly using sophisticated precision-guided weapons. These technologies provide a unique capability to paralyze enemy's forces with rapid and effective military operations and to achieve final military victory. The results of the US military operations against the regimes of Taliban (2001) and Saddam Hussein (2003) proved that such conventional forces were capable of quickly and easily defeating the enemy, who was relying on regular conventional forces and traditional conventional tactics. ${ }^{38}$ Military operations in Iraq and Afghanistan proved that it is possible to achieve military victories with much smaller conventional forces than in the past: the military operation of Iraq in 2003 was successfully executed with the conventional forces, at only half the number of those used in the Persian Gulf War in 1991.

According to the former US defence secretary Donald Rumsfeld, a military force consisting of smaller and more easily deployable combat units would ensure better use of the advantages of modern technologies, that is why the US Army has initiated the land forces reform by restructuring divisions into brigade combat teams, i.e. creating smaller and more easily deployable military units and paying more attention to the reinforcement of Special forces. ${ }^{39}$ The administration of President G.W. Bush has even rejected further development and testing of the weapon systems which cannot be quickly and easily redeployed to conflict zones, or which 'devour' money that could be used to develop light conventional forces (e.g., in 2002 the development programmes of the Crusader self-propelled howitzer and helicopter Comanche were suspended). In the beginning of the first term of G. W. Bush's presidency, the US also made the decision to substantially increase the number of strategic transport aircrafts (C-17 Globemaster, from 120 to 190 aircrafts) as they play a big role in reinforcing the capacities of the US strategic redeployment of conventional forces: the appearance of the C-17 Globemaster was perceived as one of the most important factors of successful operations of the US conventional forces in Kosovo, Iraq and Afghanistan. ${ }^{40}$

Although critics imply that not all US military victories can be attributed to the US military transformation (e.g., the success of the US military operation in Iraq in March - April 2003 was determined by a sound preparation of coalition forces and modern technologies as well as by poor preparation of the Iraqi

\footnotetext{
${ }^{38}$ Ucko D.H., The New Counterinsurgency Era: Transforming the U.S. Military for Modern Wars, Washington, D.C.: Georgetown University Press, 2009, p. 58. Boot M., War Made New: Weapons, Warriors, and the Making of the Modern World, New York: Gotham Books, 2006, p. 307-419.

${ }^{39}$ The US further continues the restructuring of 10 active divisions and 8 divisions of the National Guard into 76 brigade combat teams and 225 support teams.

${ }^{40}$ See Bolkcom C., Knight W., Military Airlift: C-17 Program Background, CRS Report for Congress, Updated October 22, 2008, http://c17foramerica.com/pdf/CRS_Report_For_Congress.pdf, 20112010.
} 
military forces ${ }^{41}$; whereas the final success of the operation in Afghanistan was determined by a sound interaction of land and air forces - the role of both special forces and high-accuracy weapons was significant but not determinant ${ }^{42}$ ), the course and results of the US military operations after the cold war show that the transformation of military conventional forces creates a huge threat for North Korean conventional forces. Americans have proven their capability to deploy large forces into regions of operation, to perfectly manoeuvre them in the battlefield and to provide them with a vast supply of precision-guided weapons. Thus, the outcome of two large-scale conventional operations was the demolition of Taliban and Saddam Hussein's regimes.

The US global missile defence system should be considered another significant element of the growing US military superiority against North Korea. Although the programme of global missile defence system development ${ }^{43}$ is not yet accomplished, Americans declare that they are capable of defending against a limited number of attacks of intercontinental ballistic missiles. ${ }^{44}$ The development of a global missile defence system has been speeded up since the US withdrew from the Anti-Ballistic Missile Treaty of 1972 with the Soviet Union; this Treaty prohibited the development of the national missile defence. Upon declaration of the US withdrawal from the Treaty of 1972, in June 2002, the US President George W. Bush justified this decision by emphasizing the threats which come from the changing security environment and also stressed the potential threat of sporadic small-scale ballistic missile attacks from certain states and perhaps even from non-state actors. The US national missile defence against incoming intercontinental ballistic missiles is based on the Ground-based Mid-Course Defence Systems, deployed in Fort Greely and Vanderberg military bases. Washington officially declared that thirty such systems will be operating by the end of 2010. Also, the US openly declared that it will not activate fourteen additional Ground-based Mid-Course Defence Systems because, given current strategic environment, there is no need to hurry the missile defence development. However, it would be wrong to conclude that the US confidence in missile defence system depends solely on the successful development of the Ground-based Mid-Course Defence programme: firstly, there is a unique integration of missile defence sensors (operating in all domains: land, sea, air, space) and missile defence interceptor systems (with different ranges), which makes it possible to provide missile defence not only for the US mainland but also for US troops deployed in other regions and US allies;

\footnotetext{
${ }^{41}$ Biddle S., Embrey J., Filiberti E., Kider S., Metz S., Oelrich I.C., Shelton R., Toppling Saddam: Iraq and American Military Transformation, April 2004, http://www.fas.org/man/eprint/biddle.pdf, 10022009.

${ }^{42}$ Biddle S., Afghanistan and the Future of Warfare: Implications for Army and Defence Policy, Strategic Studies Institute, November 2002, http://www.au.af.mil/au/awc/awcgate/ssi/afghan.pdf, 05092010.

${ }^{43}$ By the term 'global missile defence' the US usually defines a national missile defence system; regional missile defence systems are usually defined as theatre anti-missile systems.

${ }^{44}$ Ballistic Missile Defence Review Report, February 2010, p. 15, http://www.defense.gov/bmdr/, 0508 2010.
} 
secondly, the US successfully develops other missile defence systems capable of destroying missiles during their launch phase (e.g., Air-Borne Laser System, Kinetic Energy Interceptor) ${ }^{45}$, post-boost phase (e.g., Aegis System, Aegis Ashore System) and in their terminal phase (e.g., Theatre High Altitude Area Defence, $P A C-3)^{46}$. It is important to emphasize the efforts of the Clinton, G.W. Bush and Obama administrations to involve the allies (especially in the northeast Asian region) in the development of regional missile systems. ${ }^{47}$ Although the US has not been successful in persuading South Korea to join the regional missile defence system developed by the US together with Japan, nevertheless South Korea may be expected some day to acquire missile defence capabilities against short-range missiles, which will enhance common US, South Korean and Japanese missile defence capabilities against North Korea.

The Conventional Prompt Global Strike programme, unlike the transformation of conventional forces and missile defence system, has not been implemented yet. ${ }^{48}$ The birth of this programme is related to the US Nuclear Posture Review of 2001, when Americans declared their intention to develop non-nuclear attack systems in parallel with the available nuclear attack systems (development priorities of the New Triad). ${ }^{49}$ The Quadrennial defence review report of 2006 notes that prompt global strike capabilities are required in order to attack fixed (not easily accessible), mobile and re-locatable targets with improved accuracy in any location of the world upon the President's order: it is planned that these capabilities will initially consist of Trident II-D5 ballistic missiles. ${ }^{50}$ It is likely that conventional ballistic missiles will not be efficient enough to destroy mobile and re-locatable targets as they are most effective in

\footnotetext{
${ }^{45}$ Hildreth S.A., Woolf A.F., Ballistic Missile Defence and Offensive Arms Reductions: A Review of the Historical Record, CRS Report for Congress, May 25, 2010, http://www.fas.org/sgp/crs/nuke/R41251. pdf, 0509 2010; see Airborne Laser Goes Two for Three in 1st Intercept Tests, http://www.spacenews. com/military/100212-airborne-lasergoes-two-for-three-1st-intercept-tests.html, 05092010.

${ }^{46}$ THAAD System Intercepts Target in Successful Missile Defence Flight Test, http://www.mda.mil/news/10news0008.html, 05092010.

${ }^{47}$ See e.g., Kim Tae-Hyung, ,South Korea's Missile Defence Policy: Dilemma and Opportunity for a Medium State“, Asian Politics\&Policy, Vol. 1, No. 3, 371-389; Lee Chung, „A View from Asia: The North Korean Missile Threat and Missile Defence in the Context of South Korea's Changing National Security Debate“, Comparative Strategy, July/September 2005, Vol. 24, Issue 3, 253-275; Jimbo K., „A Japanese Perspective on Missile Defence and Strategic Coordination“, Nonproliferation Review, Summer 2002, Vol. 9, No. 2, 56-62.

${ }^{48}$ Given that the conventional ballistic missiles (but not UAV and aircraft fighters) will become a core capability of the Conventional Prompt Global Strike.

${ }^{49}$ Nuclear Posture Review Report, Foreword to the otherwise classified Nuclear Posture Review Report that was submitted to Congress on December 31, 2001, http://www.fas.org/sgp/news/2002/01/npr-foreword.html, 05092010.

${ }^{50}$ Ballistic missile submarines armed with Trident ballistic missiles is a sea leg of nuclear triad. The Defence Review Report of 2006 intended to replace nuclear warheads of a certain number of Trident ballistic missile with conventional nuclear warheads. Quadrennial Defence Review Report, February 2006, http://www.defense.gov/qdr/report/Report20060203.pdf, 05092010.
} 
fighting against 'soft' ${ }^{\text {'51 }}$ and immobile targets; therefore the global conventional strike capabilities should also include UAV and aircraft fighters which in the near future will still remain more effective in attacking mobile and fixed targets than long-range conventional ballistic missiles. ${ }^{52}$

The National Research Council's Committee discussed three main scenarios related to the concept of the Conventional Prompt Global Strike Capabilities for using long-range conventional ballistic missiles: the first scenario implies that the conventional strike is directed towards the nuclear weapon-launching system of the enemy state's in case this state tried to threaten the US or its ally; the second scenario envisions an attack at the terrorist leaders' meeting place or at the location of the transhipment of the weapon of mass destruction; the third scenario implies destruction of the enemy's leadership during a larger military operation. ${ }^{53}$ All these possible scenarios for using the global conventional strike and the specifics of its development capabilities revealed some potential problems, too. The concept of a response with conventional prompt strike is based on the assumption that it is possible to plan a strike and attack an enemy within less than an hour; however, this requires accurate intelligence information and a clear chain of command and communication that is absent today ${ }^{54}$; furthermore, the plans to re-arm a certain number of the Trident II-D5 ballistic missiles with conventional nuclear warheads can raise ambiguity and destabilize the nuclear deterrence balance among nuclear states: until now, all intercontinental ballistic missiles of the US were armed with nuclear warheads, and any missile launch of such type can be interpreted by opponents as a nuclear strike. ${ }^{55}$

Despite this critique, the US is not likely to give up the construction of Trident II-D5 ballistic missiles with nuclear warheads in the Ohio-class submarines; later it may also construct other types of ballistic missiles in submarines or ground-based launch platforms. In the Quadrennial defence policy report of 2010 the US declared that it intends to carry out experiments with conventional

\footnotetext{
${ }^{51}$ Today conventional ballistic missiles (in terms of their explosive power) do not pose an immense threat to the targets hidden at the depth of 70-300 ft. See Sugden B. M., "Speed Kills: Analyzing the Deployment of Conventional Ballistic Missiles", International Security, Summer 2009, Vol. 34, No. 1, 132.

${ }^{52}$ Sugden B. M., 139-140.

${ }^{53}$ U.S. Conventional Prompt Global Strike - issues for 2008 and beyond, The National Academies Press, 2008, http://books.google.lt/books?id=MNdli5ZvN68C\&pg=PA187\&lpg=PA187\&dq=national+research +council+prompt+global+strike\&source=bl\&ots=GWNtdpk8Mk\&sig=fyxfrS1Mmp_qZKMHXcLIENLs9E\&hl=lt\&ei=75udTPPzE9D5Ofye_JsM\&sa=X\&oi=book_result\&ct=result\&resnu $\mathrm{m}=5 \& \mathrm{ved}=0 \mathrm{CB} 4 \mathrm{Q} 6 \mathrm{AEwBA} \# \mathrm{v}=$ onepage $\& \mathrm{q} \& \mathrm{f}=$ false, 05092010.

${ }^{54}$ See Long A., Mistry D., Sugden B. M., "Correspondence. Going Nowhere Fast: Assessing Concerns about Long-Range Conventional Ballistic Missiles”, International Security, Vol. 34., No. 4., Spring 2010, $166-171$.

${ }^{55}$ Manzo V., An Examination of the Pentagon's Prompt Global Strike Program: Rationale, Implementation, and Risks, Center for Defence Information 2008, http://www.cdi.org/pdfs/PGSfactsheet.pdf, 05092010 .
} 
prompt global strike prototypes, including intercontinental ballistic missiles. ${ }^{56} \mathrm{In}$ the US defence budget project for 2011, presented by President Barack Obama, the costs of conventional prompt global strike programmes comprise around 4 billion dollars; these programmes also include modernization of bombers and other types of aircrafts. It seems that the allocated part of the defence budget of 2012 for this type of programmes, which should be set after carrying out the analysis of the conventional strike capabilities development in $2010^{57}$, can reflect the US ability to make quite rapid progress in the development of long-range conventional strike capabilities. According to the US analysts, in the case of the successful development of the conventional prompt global strike capabilities, the US would gain lacking conventional strike capabilities at a range of 2000 to 10000 kilometres: this means that the US would no longer be dependent on the conventional strike capabilities deployed at the military bases of allied countries.

It is difficult to claim that the US military superiority will increase due to long-range conventional strike capabilities because the option for nuclear response will remain; however the US military superiority may be noticeable against those states which have no or few nuclear weapons. This is favourable to Americans as they will always try to avoid the involvement of their own forces into military operations that cost the lives of American soldiers.

\subsection{Theoretical Assessment of North Korea's Military Power}

\subsubsection{Ideology of North Korean Regime: Son'gun Chongch'i (Military First) Policy}

Kim Jong-Il replaced his father as the leader of North Korea in 1994; four years later he started to pursue policy which prioritized military affairs. The National Defence Commission became the most important collegiate institution which took the levers of decision-making from the Politburo of the Workers' Party of Korea. According to some interpretations the new ideological attitude - "Military First" - is more likely to be the result of an inner struggle of North Korean factions (related to the takeover of power by Kim Jong-Il) than a shift of essential strategic attitudes of North Korea. ${ }^{58}$ However the strategic goals in the beginning of the rule of Kim Jong-Il partly changed: North Korea acknowledged (although

\footnotetext{
${ }^{56}$ In the future the capabilities of global conventional strike may be supplemented by the developed modern weapon systems (and their launching mechanisms) such as Hypersonic Technology Vehicle, Advanced Hypersonic Weapon. See: Conventional Prompt Global Strike, Bureau of Verification, Compliance, and Implementation, Fact Sheet, April 8, 2010, http://www.state.gov/t/vci/rls/139913.htm, 05092010 .

${ }^{57}$ Ibid.

${ }^{58}$ See Gause K.E., North Korean Civil-Military Trends: Military-First Politics to A Point, Strategic Studies Institute, September 2006, http://www.strategicstudiesinstitute.army.mil/pdffiles/pub728.pdf, 05092010 .
} 
without any official declaration) that the reunification of Koreas under the flag of North Korea, under existing conditions, is not feasible and that the aims of universal communism should be substituted with the ideology of survival. ${ }^{59}$ The ideology of survival is strongly based on the arsenal of nuclear weapons: even at times when North Korea partially complied with the international agreements regarding termination and destruction of its nuclear weapon programmes, North Korea used to declare that it would keep nuclear weapons as long as the US nuclear weapons pose a threat to North Korea. ${ }^{60}$

\subsubsection{Elements of North Korea's Conventional Military Power}

Evaluation of North Korea's conventional military power has to be based on analysis of the conventional forces and short/medium range ballistic missile capabilities. Keeing in mind that North Korea's conventional forces (in contrast to the US) were not participating in any military operations after the Cold war, its real capabilities may be assessed analysing their general development status (if they are being transformed), a level of weapons systems modernization and a quality of military training. In the end an analysis of these aspects has to show the preparedness of North Korea's conventional forces to fight the most modern conventional wars.

At the moment there is no proven evidence confirming the North Korean efforts to reform conventional forces because of the US conventional forces transformation. North Korean leaders looked at the successful US "Iraqi Freedom" operation as the "child's play", which would fail against the North Korea $^{61}$, so it is hard to believe that any initiative to start a transformation of North Korean conventional forces was launched. However, there are more convincing arguments proving that no reforms, inspired by U.S. military transformation, took place in North Korea. First of all, up to this moment North Korea has not developed or acquired the most modern information and communication technologies: North Korea has not launched any satellite into the orbit with a capability to monitor potential battlefields. ${ }^{62}$ There is no evidence that North Korea has developed or acquired modern UAV (or even combat UAV capable of destroying targets): it is believed that North Korea

\footnotetext{
${ }^{59}$ In 1998 The Supreme People's Assembly of North Korea abolished the Korean Reunification Committee. See Cha Victor D., Kang David C., Nuclear North Korea: A Debate on Engagement Strategies, New York, West Sussex: Columbia University Press, 2003.

${ }^{60}$ DPRK Foreign Ministry's Spokesman Dismisses U.S. Wrong Assertion, January 17, 2009, http://www. kcna.co.jp/index-e.htm, 05092010.

${ }^{61}$ Claim expressed by one of the defectors of North Korea regime, so there is a probability it is not true. Bermudez J.S.Jr., "North Korea and the Political Uses of Strategic Culture" in Johnson J.L, Kartchner K.M., Larsen J.A., ed., Strategic Culture and Weapons of Mass Destruction: Culturally Based Insights With Comparative National Security Policymaking. New York: Palgrave Macmillan, 2009, p. 196.

${ }^{62}$ North Korea can't expect that other countries may come into support, except maybe Iran. However, first of all, Iran has to develop such capabilities.
} 
in its arsenal has only Schmel type $\mathrm{UAV}^{63}$ developed by soviet constructors during the 1980s. In addition, North Korea falls behind the development of precision-guided weapons.

Even though a quantity of North Korean conventional weaponry is quite impressive ${ }^{64}$, its real conventional power suffers from very important shortcomings. Obsolete weaponry is one of the most evident problems - most of it was produced during the 1960s-1970s. For example no less than 3500 tanks are T-34, T-54/55 and T-62 models, old aircraft fighter models like Il-28, Mig15/17/19 dominates in the air forces (where only Mig-23, Mig-29 are more modern ${ }^{65}$ ) and the submarine fleet is almost archaic. North Korean ground air defence systems are also obsolete because they cannot destroy high flying targets. Another problem is caused by a weakening North Korean capacity to ensure the regular combat training of its conventional forces. A severe shortage of fuel disrupts daily combat training: for example, fighter pilots are unable to fly their annual hours and fewer large scale military exercises can be arranged. Shortages of food and spare parts are also considered a huge problem limiting North Korea's capacity to conduct military exercises and execute military operations. ${ }^{66}$ Although North Korea's conventional forces are confronted with the above mentioned problems, these are still capable of inflicting big enough damage to US and South Korean conventional forces at the start of a military conflict: the most dangerous threat is posed by North Korean heavy artillery units located in a nearby demilitarized zone.

In contrast to deteriorating capabilities of conventional forces, the development of North Korea's ballistic missile program is in clear progress. During the 1980s-1990s North Korea developed (by reverse-engineering soviet Scud missile technology) and deployed short-range Hwasung (range up to 700-800 $\mathrm{km}$ ) and mid-range No-Dong (range up to $1000-1200 \mathrm{~km}$ ) ballistic missiles. ${ }^{67} \mathrm{It}$ is believed that about 600 Hwasung and 200 No-Dong ballistic missiles are on alert regime.

From 1987-1992 North Korea started three more mid-range ballistic missile programs: Paektusan-1 (Taepodong-1), Paektusan-2 (Taepodong-2) and

\footnotetext{
${ }^{63}$ See The Military Balance 2009. The International Institute for Strategic Studies. London: Routledge, Taylor\&Francis Group, 2009, 396.

${ }^{64}$ Look at footnotes $20-21$.

${ }^{65}$ See The Military Balance 2009, 394-396. The number of capable aircraft fighters during the period from 1991 till 2009 fluctuated: from 732 in 1991 it shrinked till 584 in 2004 but later improved to 632 in 2009 (because of repaired or modernised Mig-29 and Mig-23P). See The Military Balance 1991-1992, The International Institute for Strategic Studies, London: Brassey's, 1991, p. 167-168; The Military Balance 2004-2005, The International Institute for Strategic Studies, London: Oxford University Press, 2004, p. 179-180.

${ }^{66}$ The Conventional Military Balance on the Korean Peninsula, http://www.iiss.org/publications/strategicdossiers/north-korean-dossier/north-koreas-weapons-programmes-a-net-asses/the-conventional-militarybalance-on-the-kore/, 0509 2010; North Korea: The Foundation for Military Strength - Update 1995, http://www.nautilus.org/publications/books/dprkbb/military/DPRKMilitaryHandbook-MarinesUpdate1995.pdf, 05092010.

${ }^{67}$ Pinkston D.A., The North Korean Ballistic Missile Program, Strategic Studies Institute, February 2008, http://www.strategicstudiesinstitute.army.mil/pdffiles/pub842.pdf, 02092010.
} 
Musudan ${ }^{68}$. Ballistic missiles Paektusan-1 and Paektusan-2 were developed for the ranges up to $2500 \mathrm{~km}$ and up to $8000 \mathrm{~km}$ each respectively. ${ }^{69}$ At the moment there is available information about three launches of the Paektusan ballistic missiles: the first launch was made in August 1998 (Paektusan-1, flight range about 1646 $\mathrm{km}$ ), the second one took place in July 2006 (Paektusan-2, disrupted after 40 seconds since launch: experts believe the flight range could be about $4300 \mathrm{~km}$ ), and the third lauch was executed in April 2009 (Paektusan-2, flight range was about $3200 \mathrm{~km}){ }^{70}$ Although no one attempt of the Paektusan- 2 missile was successful, experts think that the flight range of these missiles may reach about $7000 \mathrm{~km}$. According to LtGen M.D.Maples, then Director of Defense Intelligence Agency, tests of Paektusan-2 missiles in 2006 was proof of North Korea's technical capacity to develop intercontinental ballistic missile and make that happen very soon. ${ }^{71}$

As was previously mentioned, during the period from 1987 to 1992 North Korea initiated the Musudan missile program. ${ }^{72}$ Since North Korea never tested the Musudan missile ${ }^{73}$, it is suspected that Russian missile engineers played a prominent role in developing this missile. North Korea may have deployed up to 20 Musudan missiles with a flight range of about $3000 \mathrm{~km}$.

Assessing available open source information one may conclude that North Korea, using mid-range ballistic missiles, can reach targets in South Korea, Japan (and US military bases located in Japan territory), and Guam island in the Pacific ocean.

\subsection{Why Will North Korea Not Abandon Nuclear Weapons?}

North Korea will not abandon nuclear weapons due to the deteriorating conventional balance against the US after the Cold war. This argument is different from the nuclear deterrence theory proponents, who believe that security dilemmas force states to acquire first nuclear strike and, especially, second nuclear strike capabilities if there is an opponent threatening with nuclear weapons: North Korea's main opponent, the U.S., has pledged not to use or threaten to use nuclear weapons against non-nuclear-weapon states that are in compliance with the Nuclear Nonproliferation treaty and have no other WMDs.

\footnotetext{
${ }^{68}$ Musudan is a version of mid-range Soviet ballistic missile SS-N-6.

${ }^{69}$ Hildreth S.A., North Korean Ballistic Missile Threat to the United States, CRS Report for Congress, 2007, http://fpc.state.gov/documents/organization/76930.pdf, 02092010.

${ }^{70}$ Klingner B., New North Korean Missile Unit Reflects Growing Missile Threat, WebMemo: published by the Heritage Foundation, No. 2831, March 11, 2010, http://s3.amazonaws.com/thf_media/2010/pdf/ wm2831.pdf, 0209 2010; žr. Shin J., Chronology of North Korea 's Missile Flight Tests, May 26, 2009, http://www.cdi.org/pdfs/NKmissiletimeline5.26.09.pdf, 02092010.

${ }^{71}$ Hearing of the Senate Armed Services Committee: Annual Threat Assessment, February 27, 2007, http://www.fas.org/irp/congress/2007_hr/022707transcript.pdf, 02092010.

${ }^{72}$ It is believed that year 1992 is an exact date of the start of this program.

${ }^{73}$ Some analysts think that Paektusan-2 missile program is based on Musudan missile program.

Žr. Wright D., North Korea's Missile Program, http://www.nautilus.org/projects/dprk-policy/Wright.pdf, 02092010 .
} 
For the past years North Korea's potential to succesfully confront the US in the conventional battliefield is fast declining. Firstly, North Korea has made no attempt to reform conventional forces, which afterwards would be more capable to fight the transformed US conventional forces. ${ }^{74}$ In addition, North Korea has not developed or acquired the most modern technologies, which is a prerequisite for a symmetric response to the US military transformation. Secondly, North Korea's conventional weaponry is obsolete and some generations behind the US conventional weapons. North Korean air defence, which is critical against the transformed US conventional capabilities, would suffer exactly because of the old air defence systems: American fighters and bombers would dominate in North Korea's airspace with precision-guided weapons destroying military infrastructure and evantually causing paralysis of North Korea's land and special operation forces. Thirdly, North Korea is losing the capacity to inflict damage on US military forces in South Korea and Japan using short and mid-range ballistic missiles: South Korea and Japan (supported by the US) are developing missile defence capabilities, and more US battleships, which can be deployed near the North Korea, are equipped with Aegis missile defence systems. The probability that North Korea would attack islands in the Pacific Ocean under the US control by its mid-range missiles with conventional warheads (of Paektusan-2, Mudusan type) is low as the total number of missiles is limited, and precision-guided technology is still underdeveloped. Furthermore, it would be against the basic military rationale - the potential benefits could be significantly outweighed by the disproportionate tough US response. At the same time, there is no sound evidence that North Korea's intercontinental ballistic missiles (of Paektusan type) could reach Alaska (5000-6000 kilometers distance) or the Eastern Coast of the US (more than 8000 kilometers distance). Moreover, even if a Korean intercontinental ballistic missile was launched, its danger would very likely be neutralized by the US national missile defense system. Fourthly, the US long-range conventional strike programs pose a direct threat to North Korea's ballistic missile launch bases and their control centers, nuclear weapons development facilities as well as other vital military infrastructures (there is no data on the existing North Korean missile defense systems as well as on those systems under development). In the light of these arguments, it is doubtful if North Korea could even identify intercontinental ballistic missiles attacks against its military infrastructure and react accordingly.

Dynamics of conventional balance between the US and North Korea, which reflects continuous negative trends for the later, will force North Korea to develop further WMDs, especially nuclear weapons programs. ${ }^{75}$ This interpretation is supported by North Korea regime type's argument (it is an additional

\footnotetext{
${ }^{74} \mathrm{Also}$, there is no available information concerning North Korea's efforts to prepare assymetric measures to fight the U.S. conventional forces (for example, guerilla warfare tactics).

${ }^{75}$ It is highly likely that North Korea clearly understands negative trends in the conventional balance between its and the U.S. forces, so an assumption that North Korea still believes in a successful military engagement with the U.S. forces is rather weak, nothwistanding North Korea leaders' approach to Iraq war in 2003 as a „,child's game“.
} 
very important argument helping to explain North Korea's decision to seek nuclear weapons).${ }^{76}$ North Korea is a totalitarian communist state, which has an extended record of human rights violations, and which has no respect for democratic ideals. Therefore, the current North Korean regime could never feel safe, even if it would abandon nuclear and other weapons of massive destruction, and sign a peace treaty with South Korea and the US. Saddam Hussein regime's demolition in 2003 showed that North Korea would still probably remain a target for the US military intervention. North Korea's "nuclear disarmament story" after the cold war is a perfect illustration of the true intentions of the current North Korea's regime: all international agreements, which expressed North Korea's commitment to discontinue developing nuclear weapons and dismantle nuclear facilities, failed in the end. Both Russia and China, the states thought to have a considerable influence on North Korea, are unable (or do not want) to exercise it against North Korea's nuclear weapon policy.

Conventional balance trends between North Korea and the US and the additional supportive arguments provide a good background for some theoretical assumptions and forecasts. It is highly likely that North Korea, assessing the balance between the US and North Korean conventional forces, will not stop developing nuclear weapon programs but even speed up their development based on the available financial resources, direct and undirect foreign support (from countries like Iran, Pakistan, Syria, may be China and Russia) and technological progress. Also, the implementation of the US missile defence projects will spark North Korean attempts to initiate massive long-range ballistic missile production and complete the miniaturization of nuclear warheads. It is possible that North Korea will stop producing nuclear weapons when reliable capabilities for a minimum nuclear deterrence will be in place (may be some 20-30 intercontinental ballistic missiles with nuclear warheads): that can happen around year 2025. This assumption suggests that the US military intervention against the North Korea can be expected around 2020-2025.

\section{Conclusions}

During the past several years in a number of academic publications there have been attempts to show that North Korea is not an irrational international actor, thus a well-designed and applied negotiation strategy may push North Korea to make a decision to abandon its nuclear weapons programs. This article provides a different interpretation of the US capabilities to force North Korea to abandon its nuclear weapon development program, which argues that the conventional balance between the US and North Korean conventional forces

\footnotetext{
${ }^{76}$ This article has no intention to prove that change of the conventional balance between the U.S. and North Korea is the only factor, which influences North Korea's nuclear weapon policy - no doubt, North Korea's regime type is another quite important explanatory variable, however, it is not analyzed in depth in this article.
} 
is one of the most important factors influencing North Korea's continuous pursuit of nuclear weapons.

Since the end of the Cold war the conventional balance between the US and North Korea has constantly been moving in an unfavorable direction for the North Koreans. Transformation of the US conventional forces, enabled by the modern information and communication technologies, the long-range conventional strike programs, a continuous and rapid development of the global missile defence architecture caused a fast growing U.S. offensive conventional advantage against the North Korea's conventional forces. At the moment North Korea has no real ballistic missile capabilities to be used in US mainland attacks: the development of intercontinental ballistic missiles is not finished yet and miniaturization of nuclear warheads is probably still far from complete. North Korea's decision to abandon nuclear and other WMD programs, staying only with continuously deteriorating conventional capabilities, would probably bring the ruling North Korea's regime to the verge of collapse: it may be that the US leaders would still play with idea of overthrowing the ruling regime and making it work, especially if North Korea violated human rights and refused to implement political reforms. These arguments lead to the conclusion that North Korea, instead of stopping nuclear weapons programs, will speed up the development of both nuclear weapons and ballistic missile programs in order to acquire a minimum nuclear deterrence capability.

The interpretation that North Korea will not give up its nuclear weapons due to the US offensive conventional advantage against its conventional defense presented in this article could come under discussion on various grounds. The primary source of criticism lies in theories which hold other than realistic assumptions for explaining interstate relations. The attempt to evaluate the impact of the US military transformation on the defense policies of other actors on international stage, however, is a novel and challenging one. The case of North Korea could be perceived as especially favorable for analyzing the impact of the US military transformation on interstate relations as the current US military transformations are mainly targeted at traditional conventional capabilities, which are actually the basis of North Korea's military power. As the data on North Korea's military capabilities and military exercises is of limited availability, it is particularly difficult to evaluate all the possible forms of Korea's response to the US military transformation. In addition, North Korea's current political and military posture (the type of the political regime, continuous inclination to non-comply with international agreements) leaves little room for doubt that the toughest response to the advancements in the US military capabilities is likely to be more rapid development of nuclear weapons and intercontinental ballistic missile programs. In view of that, the US and international community's attempts to encourage North Korea to renounce its nuclear weapons development programs is unlikely to be successful. 